\title{
HEMIHYPERTROPHY AND MENTAL DEFECT
}

\author{
ARNOLD GESELL, Ph.D., M.D. \\ NEW HAVEN, CONN.
}

Anomalies of anatomic development and mental defect are often found in close association. A noteworthy example of this fact came to the writer's attention in 1913. A boy, then 13 years of age, was presented for mental examination. He was found to be mentally deficient. A physical inspection of the whole body of the boy showed this deficiency to be associated with one of the most remarkable of developmental anomalies; namely, total unilateral hypertrophy.

This anomaly is considered to be one of the rarest in the domain of medicine. Marked cases are indeed extremely few as a survey of the literature will reveal; but how frequent mild, unrecognized cases are, remains to be determined.

It is because hemihypertrophy presents a startling, though legitimate, deviation from an almost universal law of development that it constitutes a subject rich in suggestion-and perplexity.

A brief description of the physical and mental characteristics of the case here reported will serve as a basis for the discussion of this interesting condition.

\section{REPORT CF AUTHOR'S CASE}

Physical Development.-The boy in stature was fairly well developed for his age. At 20 years of age, he was 67 inches tall and 137 pounds in weight. His height-weight index at the age of 13 was also normal, being then 87 pounds for $57 \% \frac{1}{8}$ inches. He was phlegmatic in his movements and of moderate endurance. He was one of eight children. The brothers and sisters were average or normal, both physically and mentally. His parents were likewise normal and no facts of hereditary significance could be gained.

The birth was natural, without instrumental assistance, and the mother nursed her child into the second year. Dentition apparently was not delayed.

The mother asserted that she had noticed larger development on the right side in early infancy, and there can be no doubt that the condition was congenital. No children's diseases or accidents of significance were to be noted.

The accompanying tables of measures and illustrations indicate the character and degree of the hemihypertrophy. The first table indicates the physical, and incidentally the mental, status of the subject at the age of approximately 13 years. Seven years later, after adolescence had been practically completed, similar measurements were made and these are presented for comparison. They indicate that the condition of hemihypertrophy is, at least in this case, a relatively stationary one, exhibiting neither a progressive nor ameliorative tendency. 
TABle 1.-Table of Measurements (Age 13)

Height, $57 \%$ inches.

Sitting height, $291 / 4$ inches.

Weight, 87 lbs. Head: length, 18.2 inches; breadth, 15.4 inches; circum ference, 56.5 inches.

Dynamometer: right, 15; left, 11.

Chronologic age $12 \frac{1}{2}$ years; mental age $4 \frac{1}{2}$ years; intelligence quotient 36 .

\begin{tabular}{|c|c|c|c|}
\hline & Right & Left & Differerce \\
\hline Arm, length .... & 63 & 61 & 2 \\
\hline Forearm, length & 38 & 36 & 2 \\
\hline Forearm, girth & 18 & 17 & 1 \\
\hline Wrist ......... & 14 & 13 & 1 \\
\hline Hand $\ldots \ldots \ldots \ldots$ & 21 & 18.5 & 2.5 \\
\hline Middle finger, girth . & 7 & 6.5 & 0.5 \\
\hline Middle finger, length ....... & & 9 & \\
\hline 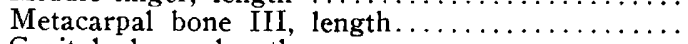 & $46 \mathrm{~mm}$ & $43 \mathrm{~mm}$ & $3 \mathrm{~mm}$ \\
\hline Capitale bone, length $\ldots \ldots \ldots \ldots \ldots \ldots \ldots \ldots \ldots$ & $20 \mathrm{~mm}$ & $17 \mathrm{~mm}$ & $3 \mathrm{~mm}$ \\
\hline 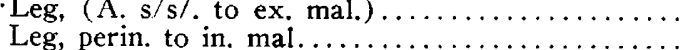 & & & \\
\hline Leg, patellar edge to in. mal.................. & & 30 & 4 \\
\hline Thigh girth $\ldots \ldots \ldots \ldots \ldots \ldots \ldots \ldots \ldots \ldots \ldots \ldots \ldots \ldots$ & 39 & 38 & 1 \\
\hline 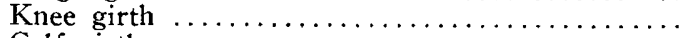 & 30 & 29 & 1 \\
\hline Calf girth $\ldots \ldots \ldots \ldots \ldots \ldots$ & & & \\
\hline Foot, metatarsal bone, length................... & $54 \mathrm{~mm}$ & $52 \mathrm{~mm}$ & $2 \mathrm{~mm}$ \\
\hline Metatarsal bone, width of head. $\ldots \ldots \ldots \ldots \ldots \ldots$ & $18 \mathrm{~mm}$ & $15 \mathrm{~mm}$ & $3 \mathrm{~mm}$ \\
\hline $\begin{array}{l}\text { Ex. canthus to antetragus } \ldots \ldots \ldots \ldots \ldots \ldots \ldots \ldots \\
\text { Int. canthus to nasolabial junction. } \ldots \ldots \ldots \ldots \ldots \ldots\end{array}$ & $\begin{array}{l}8 \\
52\end{array}$ & $\begin{array}{l}7.5 \\
4.5\end{array}$ & 0.5 \\
\hline Ear, length & 7.5 & 6.5 & 1 \\
\hline Lip, upper $\ldots \ldots \ldots \ldots$ & 4 & 3 & 1 \\
\hline Upper canine (width). & $10 \mathrm{~mm}$ & $9 \mathrm{~mm}$ & $1 \mathrm{~mm}$ \\
\hline
\end{tabular}

Examination of the blood and urine gave negative results. The red blood cells numbered 5,424,000; hemoglobin, 95 per cent.; white blood cells, 10.000; polymorphic cells, 68 per cent.; large mononuclears, 21 per cent.; small mononuclears, 11 per cent.

\section{TABLE 2.-Table of Remeasurements (Age 20)}

Height, 67 inches.

Sitting height, $33 \%$ inches.

Weight, 137 lbs. Head: length, 18.7 inches; breadth, 15.9 inches ; circumference 59 inches.

Dynamometer: right 31 ; left, 22.

Chronologic age, 20 years; mental age, 5 years, 8 months; intelligence quotient, 35 .

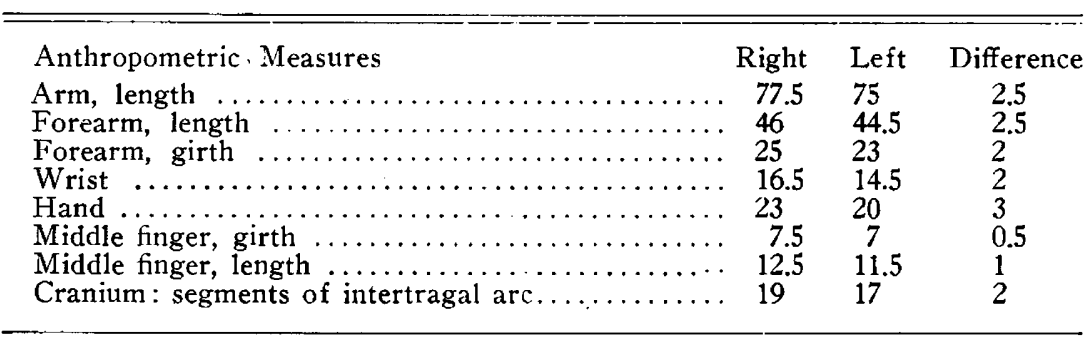


The axillary temperature was equal on both sides.

The asymmetry was not very marked. It might easily escape observation, though it caused the boy to $\operatorname{limp}$ to a moderate extent.

Careful inspection revealed mild gigantism involving apparently all of the right side: the right ear was longer, the right half of the nose larger, the right nares twice that of the left in diameter, the right palpebral fissure was wider; on the same side the cheek and lips were fuller; the arm was longer, the right hand was relatively more enlarged than some of the other structures; the right leg and foot were similarly enlarged; the penis was definitely enlarged to the right of the median line.

The opthalmoscope showed no marked difference in the right fundus, though the veins were fuller. There were no differences in refraction in the two sides.

Throat examination revealed no marked difference in the tonsils. The uvula was bifid; the epiglottis was definitely asymmetrical, but curiously enough, the left side was thicker than the right; the posterior rim was also bulkier on the left side, the whole right of the epiglottis apparently being in the infantile condition.

A cast (Fig. 5) of the upper palate and teeth showed considerable deformity. The placement of the teeth was very defective on the right side giving the gums a thicker appearance on that side. The right upper canine was $10 \mathrm{~mm}$. wide and $9 \mathrm{~mm}$. thick; the left canine was $9 \mathrm{~mm}$. wide and $8 \mathrm{~mm}$. thick. The eruption was further advanced on the left side, which is contrary to rule.

The skin was by no means normal. The peculiarities, presently to be noted, were more pronounced on the right side but were by no means limited to that side. The skin was dry and there was a definite tendency to ichthyosis. Small keratinous patches were present about the elbows and the ankles. Most prominent and characteristic were extensive areas of telangiectatic congestion which gave the skin a marbled, and, in some areas, a decidedly livid aspect; for example, the dorsal surface of the right hand and the lateral surface of the leg. On last examination the right leg had developed marked varicosities (Fig. 4).

On palpation the hypertrophied side had a more doughy feel than the left. This suggested redundancy of the subcutaneous tissue, but the roentgen rays showed that the bones themselves had participated in the hypertrophy. The measurements showed that all the members of the right side were not proportionately hypertrophied.

Mental Development.-The mental development of this boy has shown a consistent retardation dating no doubt from birth. He was over 2 years old when he began to walk; he began to say "mama" and "papa" at the age of 3 ; but he did not begin to "talk" until about the age of 5 . Even now he speaks in phrases and short sentences and has a very childish vocabulary. He entered the first grade of the public schools at the age of 9 . He stayed in this grade two years and was gradually promoted into the higher grades out of deference to his physical development. His academic attainments after years of schooling never rose to those of grade 2. During all these years he has been considered a docile, amenable, cheerful and neat boy. He has been able to read a few words, to spell a few others and to repeat a few number combinations. Persistent drill has left some precipitate, but there has been a restricted intellectual development during the seven years of teens in which I have observed him. He is now 20 years old and, although his intelligence is more mature than it was at the age of $12 \frac{1}{2}$, he still must be classified as an imbecile. 
At the chronologic age of a little less than 13 , he had a mental age of $4 \frac{1}{2}$ years by the Vineland revision of the Binet tests. At that time he could not tell which was the longer of two lines, one 7 , and the other $6 \mathrm{~cm}$. in length; he was also unable to repeat a sentence consisting of ten words. In another year he was able to meet both of these tests, but otherwise he showed little progress. After six more years of growth, he is still unable to distinguish between right and left and cannot tell whether it is morning or afternoon; but he is able to count 13 pennies, and he can describe a simple picture. The net result is that now at the age of 20 he has a mental age of 5 years and 8 months. In other words, it has taken about seven years for this boy to accomplish the equivalent of one year of mental growth. This growth has been as steady and consistent as his physical growth; but it has been slower and on a different level. There has been no deterioration. Seven years ago the ratio between his mental age and chronologic age was $4 \frac{1}{2}: 12 \frac{1}{2}$, which expressed on a percentage basis gives an intelligence index or quotient of 36 . By a similar method of calculation, using the Stanford revision of the Binet scale, we find that his present intelligence quotient (IQ) is 35 . Though these two quotients were not derived by precisely the same method, they are comparable and true to the facts of the case. We cannot say that this youth has shown no mental growth during his teens; but viewed in relative terms, we are obliged to conclude that there was no increase in his caliber. His IQ has remained fairly constant.

His actual mental status is summarized in the accompanying normgraph (Fig. 8), which in terms of age norms, plots his ratings. In height and weight he was, and is, at standard; but in the psychophysical measurements obtained by the dynamometer and spirometer, and in the mental and educational measures he is at the level of a beginner at school. On this level he will remain. At the age of 20 his drawings of a house, man and bird are characteristic of a kindergarten mentality.

It would be unjust, however, to leave this sketch without referring to the surprising success which this boy has made in life in spite of his limitations. His mother, though a struggling widow with eight children, was loathe to consider commitment to an institution. We respected this attitude and repeated efforts were made to find a simple occupation for him. There were great difficulties as employers would not take the necessary risk, pains and patience. Finally, the cooperation of neighbors was enlisted and he got a job as a scullery boy at a downtown café, with hours from 8 to 5 and wages of $\$ 5.00$ a week. For a whole year he has been doing regular, satisfactory work, the pride of his mother. And incidentally this is an example of the sort of thing that local communities might deliberately do to control the problem of feeblemindedness.

\section{SURVEY OF RECORDED CASES OF HEMIHYPERTROPHY}

Thomas Wedders, with a nose reputed to be $71 / 2$ inches long, was a famous character in an earlier day. The scientific literature on the subject of hypertrophy, however, goes back to the publication of a case by Wagner in Germany, in 1839, and one by Desvouges in France in 1856, and by Adams in England in 1858. Osler, writing in 1879, gave the number of cases of congenital hypertrophy reported to date as twelve. Ely Leblanc, who in 1897 wrote his medical thesis on the subject, made an exhaustive canvass of the literature and 


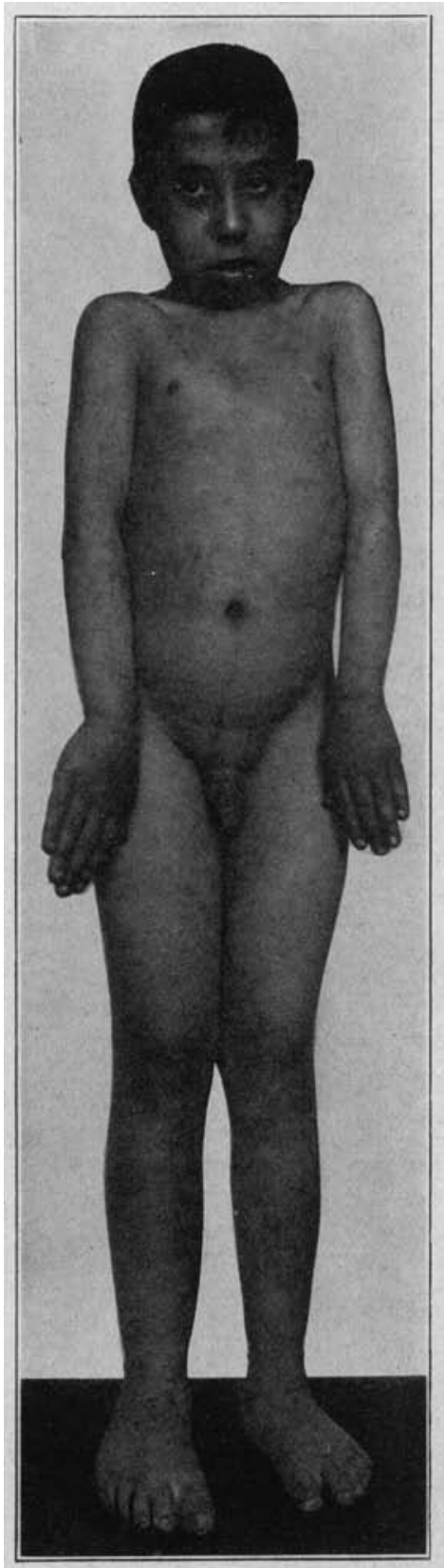

Fing. 1.-Hemihypertrophy; subject aged 13 
assembled seventy-nine case, of which twelve were cases of total hemihypertrophy, thirty-eight of partial, nineteen involved but one extremity, six the face and four were crossed. Lewin assembled sixty cases of hypertrophy limited to fingers and toes. David M. Greig, in 1898 , in the Edinburgh Hospital Reports reviewed a collection of fortytwo cases. This collection was confessedly incomplete and included a large proportion of cases of partial hypertrophy as distinguished from total unilateral hypertrophy or true hemihypertrophy. Greig's valuable monograph deals chiefly with unilateral cephalomegaly (unilateral hypertrophy limited to the head and face), of which he collected thirty-five cases. I am indebted to Greig and Leblanc for references to several cases considered below.

I was able to collect forty cases of true hemihypertrophy, and this may be regarded as a reasonably complete list of the cases now available in the medical literature. Table 3 gives a list of these cases. For comparative purposes a tabulation of thirty cases of partial and crossed hypertrophies is included. Table 4 is by no means complete, for such partial or restricted hypertrophies are much more common than true total hemihypertrophy. It is not unlikely that they frequently have a pathology and etiology identical with that of hemihypertrophy. We shall, however, limit our discussion to the latter condition.

An analysis of Table 3 shows that of forty reported cases only five patients were adults, nineteen were male, seventeen female, and four not specified as to sex. In twenty-seven, or almost 70 per cent. of the cases, the total unilateral hypertrophy was on the right side. For every case of left-sided hemihypertrophy there are two right-sided cases. In fifteen of the cases it was definitely stated that all the tissues were involved in the hypertrophy. In nineteen cases abnormalities of the skin were mentioned as a complication, while in three cases the skin was reported as normal; in the remaining number no facts on this point were given. The data as to mental status are incomplete. In twenty-nine cases no facts are given; in many of the instances, indeed, the subject was too young to make the mental status obvious. In only six cases was the mentality reported as normal and in five cases, or 13 per cent. of the total, it was reported as defective.

A general statistical summary of the facts in Table 4 shows a similar picture. Only three of the listed cases of partial hypertrophy occurred in adults; males were slightly more numerous (fourteen to eleven); the right side was more frequently involved than the left in the ratio of 16:9. In five cases, however, both sides were partially involved in the same person. Skin complications were reported in eleven cases; in only one case were they recorded as absent. Mentality 


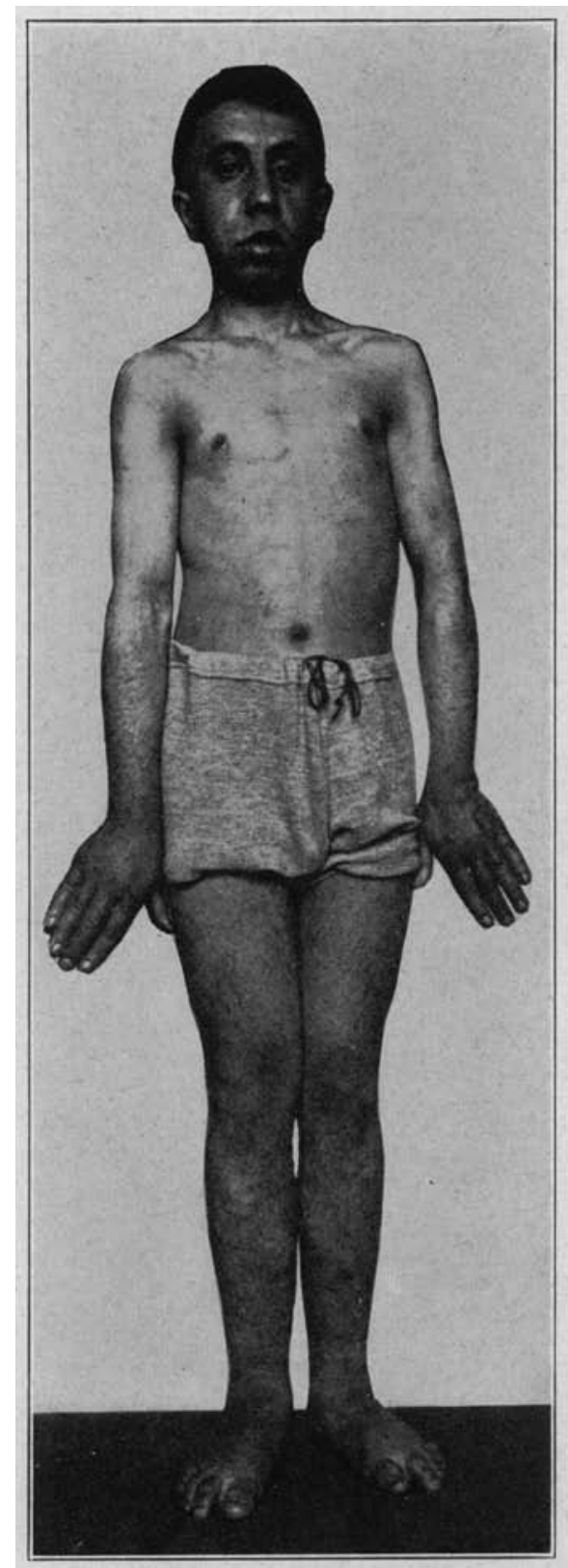

Fig. 2.- Same subject as in Figure 1 , aged 20. 
TABLE 3.-CASES of TOTAL Hemihypertrophy

\begin{tabular}{|c|c|c|c|c|c|c|}
\hline Author & Sex & Age & Side & $\begin{array}{l}\text { Mental- } \\
\text { ity }\end{array}$ & $\begin{array}{l}\text { Skin Compli- } \\
\text { eations }\end{array}$ & Special Features \\
\hline Adams, S. S. ....... & $\mathbf{M}$ & 10 & Right & Normal & Telangiectasis & Hair darker and longer \\
\hline Ahlfeld.............. & $\mathbf{F}$ & 2 & Left & & & on right side \\
\hline A rnheim........... & $\mathbf{F}$ & 2 & Right & & $\begin{array}{l}\text { Nevuspilosus } \\
\text { hypertrichosis }\end{array}$ & $\begin{array}{l}\text { Right teeth adult in size; } \\
\text { right kidney } 1 \mathrm{~cm} \text {. long: } \\
\text { er; tongue asymmetric; } \\
\text { necropsy }\end{array}$ \\
\hline Bassoe.............. & $\mathbf{M}$ & 16 & Left & $\ldots \ldots$ & Nevi pigmented & \\
\hline Broca.............. & $\mathbf{M}$ & 14 & Left & Subnor- & & \\
\hline Brüning............ & $\mathbf{M}$ & 1 & Right & W. & $\begin{array}{c}\text { Nevi pigmented } \\
\text { angloma }\end{array}$ & $\begin{array}{l}\text { Hypertrophy of } 2 \text { fingers, } \\
\text { left side }\end{array}$ \\
\hline Bull................ & $\mathbf{F}$ & & Left & & & \\
\hline Burlet.... & $\mathbf{F}$ & 27 & Right & $\begin{array}{l}\text { Subnor- } \\
\text { mal }\end{array}$ & $\begin{array}{c}\text { Vaseularity } \\
\text { increased }\end{array}$ & $\begin{array}{l}\text { Temperature }+ \text { on right } \\
\text { side }\end{array}$ \\
\hline Cagiati............. & $\mathbf{F}$ & $15 \mathrm{mo}$. & Left & $\ldots \ldots \ldots$ & $\begin{array}{l}\text { Nevi pigmented } \\
\text { keratosis }\end{array}$ & 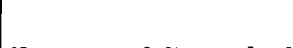 \\
\hline Demme.............. & $\mathbf{F}$ & $1 \mathrm{wk}$. & Left & .. & $\ldots \ldots \ldots \ldots \ldots$ & $\begin{array}{l}\text { Necropsy: left cerebral } \\
\text { hemisphere }+\end{array}$ \\
\hline Desvouges. . & $\mathbf{M}$ & 17 & Right & & Nevi; varices & $\begin{array}{l}2 \text { left tofs }+: \text { right side } \\
\text { stronger }\end{array}$ \\
\hline Faton,............. & $\mathbf{M}$ & 10 & Left & & & \\
\hline Finlayson...... & $\mathbf{F}$ & $18 \mathrm{mo}$. & Right & & $\begin{array}{l}\text { Dark red on } \\
\text { right side }\end{array}$ & $\begin{array}{l}\text { Skin on right side blue on } \\
\text { crying }\end{array}$ \\
\hline Fortescue-Brickdale. & $\mathbf{M}$ & 9 mo. & Right & Normal & Nevi & Cors \\
\hline $\begin{array}{l}\text { Fischer, } \mathrm{H}, \ldots \ldots \ldots \ldots \\
\text { Fowler.............. }\end{array}$ & $\underset{F}{F}$ & $\stackrel{9}{10} \mathrm{mo}$ & $\begin{array}{l}\text { Right } \\
\text { Right }\end{array}$ & $\cdots$ & $\begin{array}{l}\text { Venous ectasia } \\
\text { Nevi }\end{array}$ & Right side more fatigable \\
\hline Gesell.................. & $\mathbf{M}$ & 13 & Right & $\begin{array}{l}\text { Subnor- } \\
\text { mal }\end{array}$ & $\begin{array}{c}\text { Telangiectatic } \\
\text { patehes }\end{array}$ & $\begin{array}{l}\text { Reversed asymmetry of } \\
\text { epiglottis }\end{array}$ \\
\hline Gordinier........... & $\mathbf{M}$ & 65 & Left & Normal & Nev & $\begin{array}{c}\text { Necropsy: left cerebral } \\
\text { hemisphere }+\end{array}$ \\
\hline Hornstein........... & $\mathbf{F}$ & 2 mo. & Right & & Nevi & $\begin{array}{l}\text { Necropsy: connective tis- } \\
\text { sue hyperplasia }\end{array}$ \\
\hline Hutehinson.......... & $\mathbf{M}$ & 5 & Right & & $\cdots \cdots \cdots$ & $\begin{array}{l}\text { Necropsy: suprarenal, tes- } \\
\text { ticle, tonsil, etc. }\end{array}$ \\
\hline Jacobi... & $\cdots$ & $3 \mathrm{mo}$. & Right & & & \\
\hline La & . & Adult & Right & & & \\
\hline $\begin{array}{l}\text { Log } \\
\text { Mas }\end{array}$ & $\cdots$ & $\begin{array}{l}4 \\
1\end{array}$ & $\begin{array}{l}\text { Right } \\
\text { Right }\end{array}$ & & & \\
\hline MeGregor.... & $\ddot{\mathbf{M}}$ & 10 & Rjght & $\cdots \ldots \ldots$ & $\ldots \ldots \ldots$ & $\begin{array}{l}\text { Necropsy: right optic } \\
\text { thalamus }+\end{array}$ \\
\hline Milne............... & $\mathbf{F}$ & $19 \mathrm{mo}$. & Right & & & $\begin{array}{l}6 \text { teeth on right side; } 1 \text { on } \\
\text { left side }\end{array}$ \\
\hline Milne.. & $\mathbf{F}$ & 12 & Right & & Telangiectasis & $\begin{array}{l}\text { Right forefinger and } \\
\text { thumb normal }\end{array}$ \\
\hline Monod. & $\mathbf{M}$ & 19 & Right & & $\begin{array}{l}\text { Telangiectatic } \\
\text { varicosities }\end{array}$ & $\begin{array}{l}\text { Temperature }+ \text { on right } \\
\text { side }\end{array}$ \\
\hline Möbius............... & $\mathbf{M}$ & 14 & Left & & $\begin{array}{c}\text { Telangiectatic } \\
\text { marbling }\end{array}$ & Pains in left arm \\
\hline Mummery........... & $\mathbf{M}$ & $\mathbf{5}$ & Left & Normal & $\ldots \ldots \ldots \ldots \ldots$ & $\begin{array}{l}\text { Left side apparently grew } \\
\text { faster in } 2 \text { years }\end{array}$ \\
\hline Ollier... & $\mathbf{F}$ & 27 & Right & $\begin{array}{l}\text { Subnor- } \\
\text { mal }\end{array}$ & & $\begin{array}{l}\text { Temperature }+ \text { on right } \\
\text { side; cephalalgia }\end{array}$ \\
\hline $\begin{array}{l}\text { Pollosson............ } \\
\text { Redard............. }\end{array}$ & $\begin{array}{l}\mathbf{M} \\
\mathbf{M}\end{array}$ & $\underset{2}{\text { Adult }}$ & $\begin{array}{l}\text { Right } \\
\text { Right }\end{array}$ & Normà & $\cdots \cdots$ Nevi $^{\prime}$ & $\begin{array}{l}\text { Elephantiasis (?) } \\
\text { Hypertrophy right foot } \\
\text { very marked; tempera- } \\
\text { ture right side + }\end{array}$ \\
\hline $\begin{array}{l}\text { Schiller............ } \\
\text { Telford......... }\end{array}$ & $\begin{array}{l}\mathbf{M} \\
\mathbf{F}\end{array}$ & $\begin{array}{r}11 \\
7\end{array}$ & $\begin{array}{l}\text { Left } \\
\text { Right }\end{array}$ & & $\begin{array}{l}\text { Nevi. vari- } \\
\text { cosities }\end{array}$ & $\begin{array}{c}\text { Rickets equal on both } \\
\text { sides }\end{array}$ \\
\hline & $\mathbf{F}$ & $18 \mathrm{mo}$. & & $\begin{array}{l}\text { Subnor- } \\
\text { mal }\end{array}$ & & $\begin{array}{l}\text { Thyroid absent? cretin- } \\
\text { ism? }\end{array}$ \\
\hline Tilanus. & $\mathbf{F}$ & 10 & Right & Normal & $\begin{array}{l}\text { Telangiect atic } \\
\text { marbling }\end{array}$ & Right side stronger \\
\hline $\begin{array}{l}\text { Turbil.................. } \\
\text { Wagner.............. }\end{array}$ & $\stackrel{\mathbf{M}}{\mathbf{M}}$ & $\begin{array}{l}2 \text { wk. } \\
11\end{array}$ & $\begin{array}{l}\text { Left } \\
\text { Left }\end{array}$ & & $\begin{array}{l}\text { Telangiectasis: } \\
\text { blue pigment }\end{array}$ & \\
\hline
\end{tabular}


was reported normal in five cases and abnormal in three, the subnormality in two instances being associated with marked cranial asymmetry.

Of peculiar interest is the relatively frequent association of mental defect and hemihypertrophy. In 13 per cent. of the cases in the series this association is present. If the mental status could have been

TABLE 4.-Cases of Partial Hypertrophy

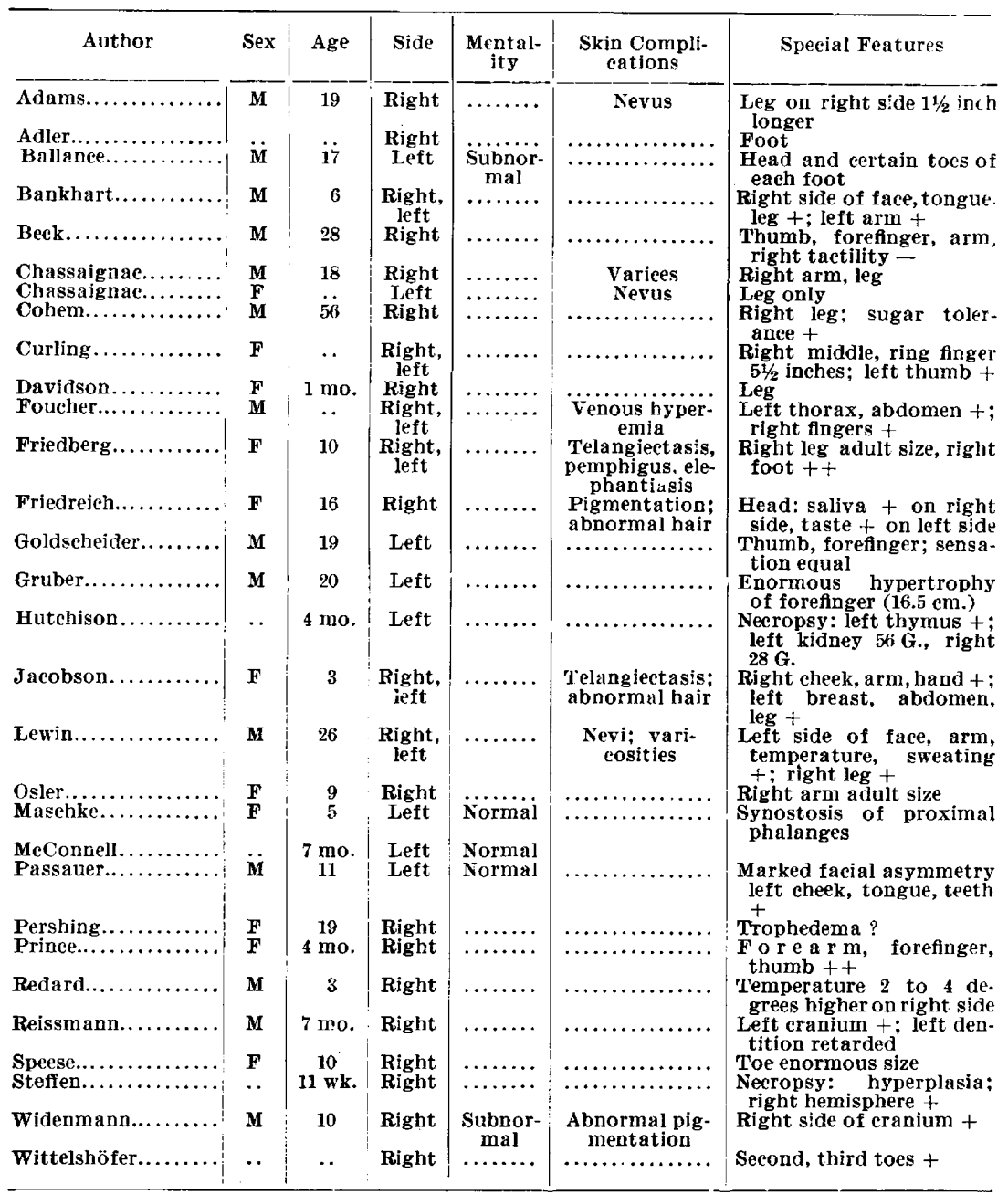

determined in every instance, it is possible that the proportion might have been markedly increased. The facts clearly indicate that hemihypertrophy should be added to the list of developmental anomalies which bear some lawful relation to the incidence of mental deficiency. What is the nature of that relation? 


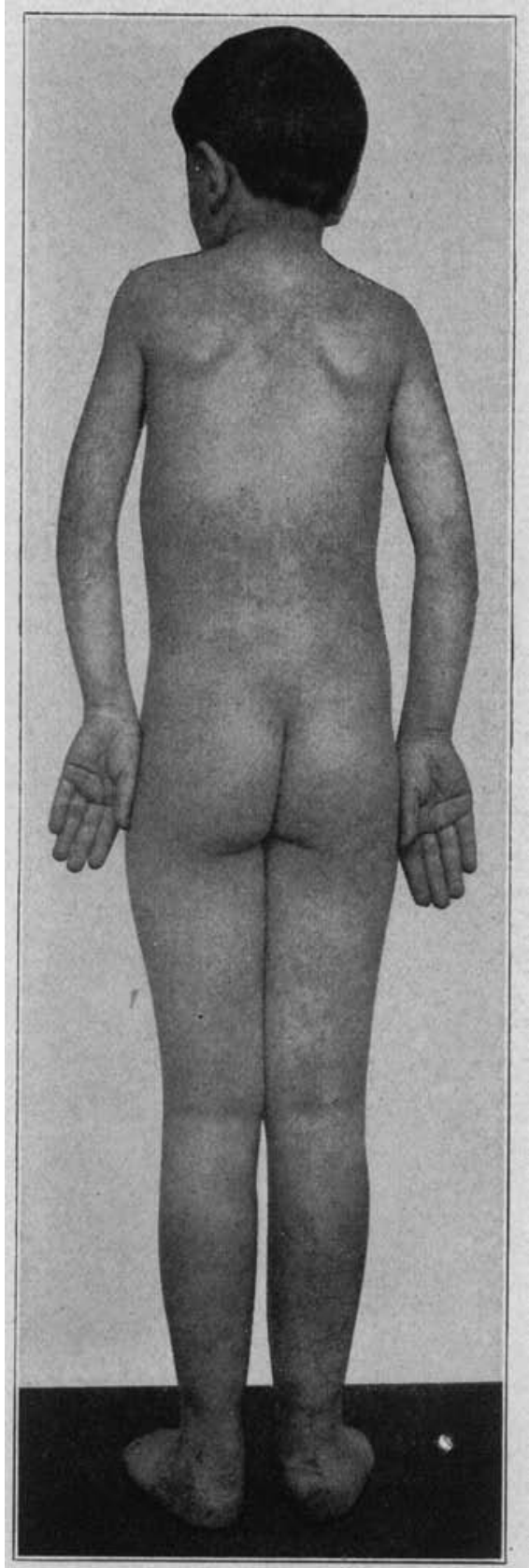

I’ig. 3.--Posterior view of subject in Figure 1, aged 13. 


\section{THE ETIOLOGY OF HEMIHYPERTROPHY}

Since we do not know the true cause of hemihypertrophy, there is no dearth of etiologic theories. These "explanations" range from maternal impressions to internal secretions. A German mother ascribed the hemihypertrophy in her son to the fact that during pregnancy she had seen a youth of gigantic proportions in the market place. Presumably she saw only one side of this giant.

One writer attributes hemihypertrophy to an inherent tendency of the tissues to appropriate an excess of nutriment, but, as Ballantyne remarks, this statement is more ingenuous than ingenious.

Fortescue-Brickdale advances a venturesome biochemical theory. He suggests that the condition is due to an irregular distribution in the tissues of the anchoring substance which interacts with the glandular secretions which determine growth.

Another group of theories ascribes the hypertrophy to vascular lesions, calling attention to the frequency of vascular and skin complications and to the analogy of "naevus neuroticus unius lateris." One view is that an embryonic disturbance establishes a preeminence in the blood supply of one side or one part. Once established, this preeminence causes a permanent overgrowth of the favored side. This explanation is similar to that which ascribes right-handedness to the richer blood supply of the left hemisphere. Partial vasomotor paralysis has been suggested (Virchow); also incomplete development of the middle arterial coat. Pollosson regards a disturbance of the lymphatic system as the etiologic factor. But if the lesion is a vascular one, what is its origin? Is it hereditary?

There is no evidence that hemihypertrophy is hereditary. Bruns found only one case in the literature in which macrodactylism was present in several members of a family. There is one record of a family with apparently hereditary enlargement of the left hand, but we know of no instance in which two members of the same family or related members presented hemihypertrophy. To be hereditary the differential cause of a character must be present in the germ cell. Hemihypertrophy is congenital, but in origin it is probably embryonal and not germinal.

Hemihypertrophy may easily date back to some disturbance during the early embryonic period. The results of experimental teratology have shown that gravity, mechanical and other influences may induce monstrosities of various kinds. It is conceivable that a slight deviation from the harmony of physical influences surrounding the embryo may be competent to initiate a partial or unilateral hypertrophy in ways similar to those demonstrated in the laboratory. If the influence is teratologic, it may well go back as early as the fourth week in the embryonic period during the cleavage of the mesoblastic somites. 
Wieland therefore regards hemihypertrophy as an embryonal malformation: "By continuous or intermittent proliferation processes in these somites during the intra-uterine life, the more severe types of congenital hypertrophy arise."

Leblanc similarly traces the lesion to the primitive embryonic neurotomes and their associated vasomotor center.

Greig takes the same general view and makes it more explicit. He argues that in the embryo all motor nerves may be regarded as trophic, because if they are destroyed or injured the parts supplied by them are more or less abnormally developed. Therefore it is to a central lesion or irritation of certain nerves brought about by intra-uterine

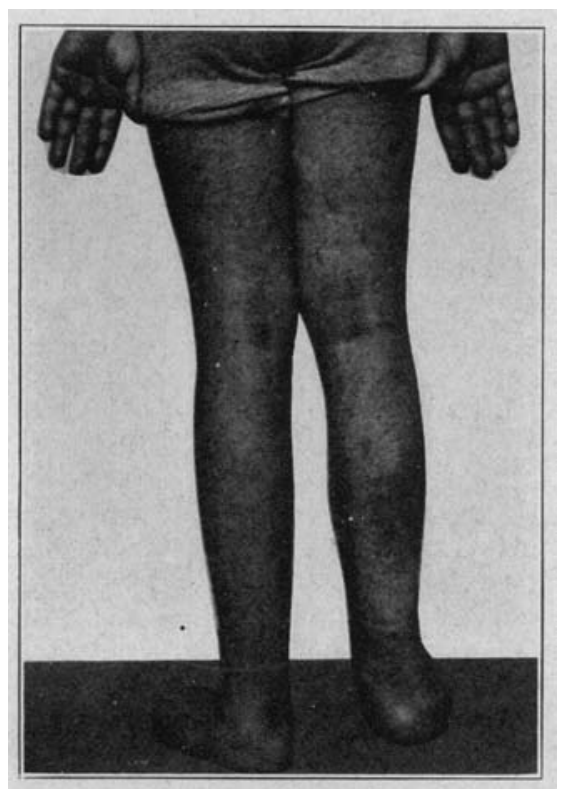

Fig. 4.-Posterior view of right leg showing areas of cutancous congestion; subject aged 20 .

meningitis or cerebritis that one must look for the origin of unilateral hypertrophy. Pathologic evidence adduced to support this interpretation is the enlargement of the foramina of certain nerves suggesting a previous inflammatory process.

If it is impossible to establish the existence of such definite extrinsic causes operating in the embryonic period, it will be necessary to search so far as we can among the deeper determinations of growth and deveiopment.

Growth depends on two groups of factors-internal and external. In the latter group are included the activators, hormones, vitamines, 
food accessories and secretions. The action of these agencies, however, is general and mediated through the general blood supply. It is difficult to conceive llow that action could be diminished or increased in a restricted manner in one member like the middle finger, or one side of the whole body to the exclusion of the other. Among the internal factors of growth are the so-called determiners which are already laid down in the fertilized ovum. It may be that for all paired or bipartite organs, instead of one determiner, there are two, or two groups of determiners, and the basis of asymmetry depends in some unknown way on an inequality of these primary determiners.

One investigator considered that in his case of hemihypertrophy the enlarged side looked fully a year older than the other, and that the ossification at the epiphyses of the forearm was, on that side, more advanced. Ossification is a criterion of physiologic age. A man is as old as his arteries, and a child, if we follow Dr. Rotch, is as old as the bones of his carpus. Does this mean that due to the difference in growth factors our boy with hemihypertrophy has three ages: his chronologic age, a right physiologic age and a left physiologic age? The fact that detention on the hypertrophied side is often precocious to the extent that there will be eight teeth on that side and none on the other is not altogether inconsistent with this fancy.

\section{TWINNING AND ASYMMETRY}

It is natural that a discussion of the etiology of hemihypertrophy should finally bring us to problems of double physical personality and twins. Further researches into the biology of twinning may bring the remarkable phenomenon of unilateral hypertrophy more completely within our comprehension; may even prove it to be on closer scrutiny more frequent and less anomalous than we had supposed. Indeed, even now, all things considered, the real marvel is not the occurrence of hypertrophy but the fact that hemihypertrophy is such an extreme rarity.

"By twinning we mean production of equivalent structures by division." This statement is taken from the biologist Bateson, who regards the power to divide as a fundamental attribute of life. The tendency to symmetry, to bilateral equivalence or mirror imaging is so general that it also must be regarded as a fundamental of biologic mechanics. Hemihypertrophy accordingly may be conceived as some profound inaccuracy in the natural process of developmental duplicity. It is not as monstrous as the double monster, but it may have a related morphogenesis. At any rate, we can safely assume that hemihyper- 
trophy is not an artifact really consisting in a hemi-atrophy. It is evidently a mild unilateral gigantism of an indiviclual whose lesser somatic half is normal.

In a certain biologic sense we may regard every bilateral individual as being a pair of twins. H. H. Newman, in his fascinating work on the "Biology of Twins," holds that monozygotic twinning-where a single egg produces two offsprings-is "a phenomenon that should be considered as only a phase of the much more general phenomenon of symmetrical division. The development of the right and left hand homologous organs in a bilateral organism is

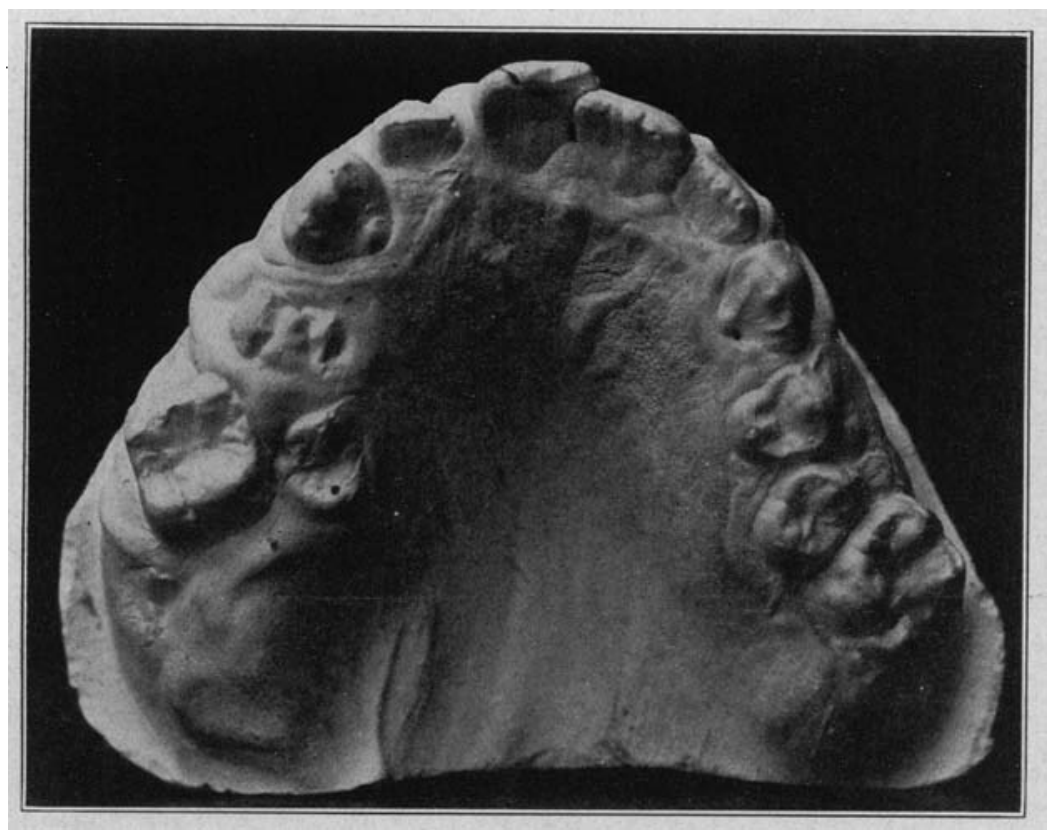

Fig. 5.-Cast of palate and upper teeth.

essentially a twinning process." This author also observes that "the whole matter of bilateral development appears to be quantitative in nature, in that the same type of process may go not so far or further than normal." Just as there may be an inhibition of the normal culmination of the process of bilateral division (as in the single median cyclopic age), so there is frequently an excess of division resulting in the two bilateral structures becoming completely segregated, as when a single inclividual develops two heads or two tails, while the remainder of the organism is a more or less normal individual. Newman, like Bateson, regards the phenomenon of twinning as a fundamental process which is almost universal in the field of biology. 
From this point of view, hemihypertrophy may be interpreted as an atypical or imperfect form of twinning, a variant of the same process which may produce a double-headed monster or a perfectly, ordinary normal individual-an ordinary individual being an organism in whom there has been a precisely baianced inhibition on the biologic process of bilateral doubling.

The actual mechanism of this regulative control over symmetry of size and form remains somewhat enigmatic in spite of much biologic investigation. Davenport regards size or stature as a unit character of inheritance subject to Mendelian principles; but this does not assist us in interpreting the curious stature anomaly embodied in hemihypertrophy.

Newman has made suggestive researches into heredity and organic symmetry in armadillo quadruplets. He has noted some cases in which "one lateral half of the body has quite a different number of scutes from the other half, and one of these halves resembles the maternal condition." Since each set of quadruplets have the same genetic constitution as they arise from one zygote, he concludes that some irregularity in the mechanism of the mitotic cell-division is responsible for the anomalies of symmetry. This factor is by no means a simple one. "Now in the armadillo there are many evidences of a system of symmetry common to all of the quadruplets, upon which has been superimposed a secondary symmetry system between twins. This in twins is more or less obliterated by a tertiary symmetry between the antemeric halves of the single individual."

R. G. Harrison discusses rules of symmetry in his monograph "On Relations of Symmetry in Transplanted Limbs." This study is based on 462 cases of grafting of limb buds in amblystoma punctatum. He agrees with Morgan that the potential factors of symmetry reside in the constitution of the egg. "It is the intimate protoplasmic structure that underlies symmetry." Likewise reversal of symmetry. "As an alternative to the hypothesis of rotation, we might consider reversal as due to reversal of molecular asymmetry according to analogy with the behavior of optically active compounds." "There is an analogy between the production of enantiomorphic limbs and the production of situs inversus viscerum, as effected by Speeman. Either the reversal may be due to reversal of the intimate structure, or it may take place in spite of the intimate structure through the direct action of mechanical factors on the individual parts of the differentiating system." 1

1. Speeman obtained a large number of twins in Triton by constricting the eggs in segmentation stages or in early blastula. In many of the cases one individtual, usually the right, developed complete situs inversus viscerum. 
Another form of asymmetry, even more startling and drastic that hemihypertrophy is that of gynandromorphism. A gynandromorph is an animal that is male on one side and female on the other. This differentiation may include the reproductive organs, gonads and ducts. Usually it is longitudinally bilateral, but it may be anteroposterior.

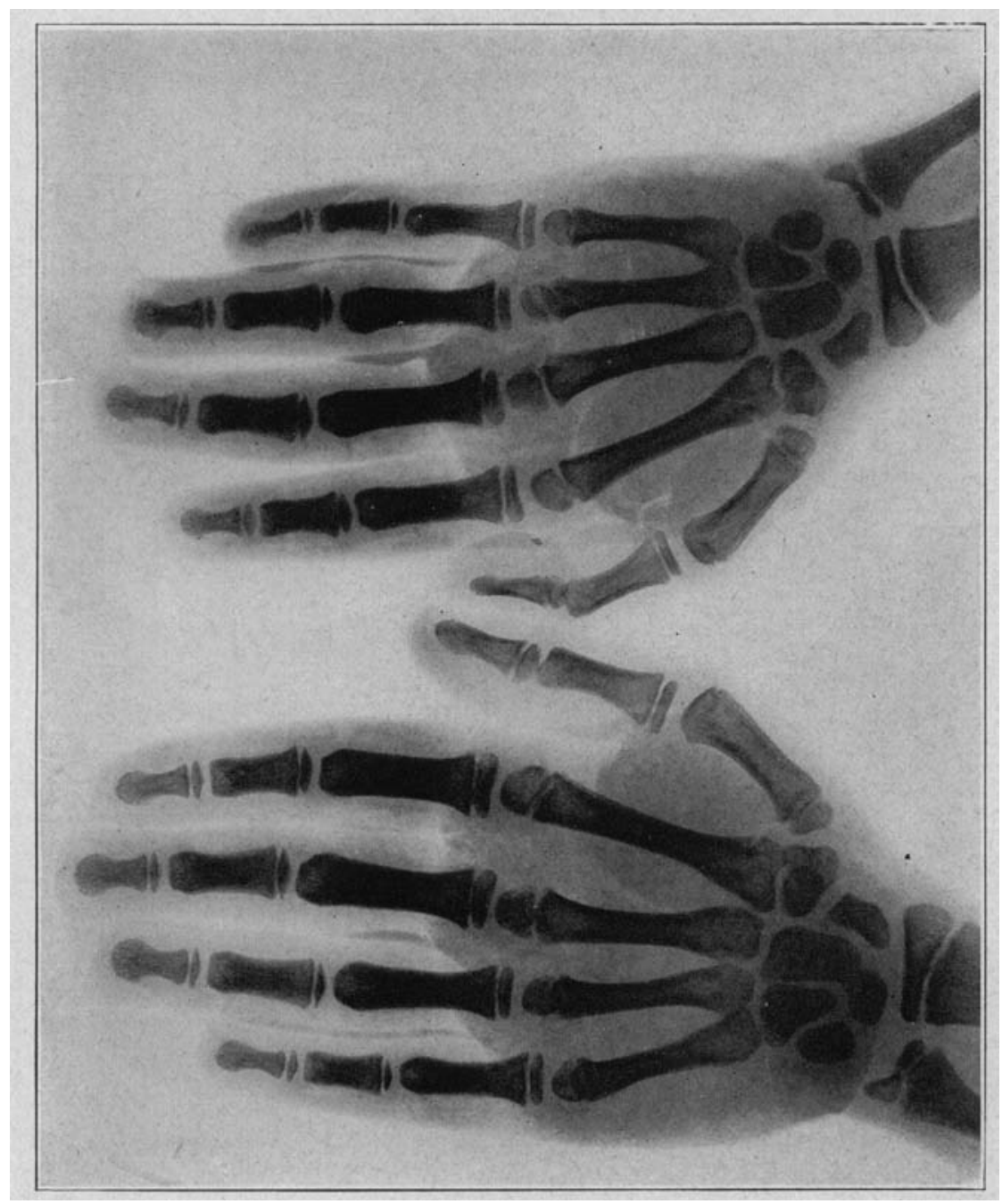

Fig. 6.-Roentgenogram of hands of subject at age of 13 .

This curious phenomenon is most frequent in insects but has been reported in birds and in a few mammals. A beautiful case was described in a mutillid wasp in which the male half of the body was black and winged like the male while the female half was a rich red and wingless. 
The problem of gynandromorphism has been extensively studied by F. H. Morgan and C. B. Bridges and reported in their contributions to the genetics of Drosophila melangaster. They found one gynandromorph among every 2,200 flies. The authors consider a gynandromorph a hybrid whose genes are carried by the sex chromosome; and they give definite evidence that the peculiar sex mosaic condition is due to an elimination of one $\mathrm{X}$ chromosome, usually at some early division of the segmenting nuclei.

MENTAL DEFECT IN RELATION TO HEMIHYPERTROPHY

The foregoing discussion indicates that hemihypertrophy, even though it is frequently associated with mental defect, should not be classified as a stigma of degeneracy. It is congenital, but it is apparently not due to an intrinsic imperfection in the genetic constitution of the germ cells. A stigma of degeneracy would denote such an imperfection. Hemihypertrophy rather denotes an abnormal deviation in morphogenesis and is to be classified as an anomaly of development.

Anomalies of development are found with a high degree of fre quency among the feebleminded. Even in growth of stature they show significant departures from the normal. As Goddard found, "low grade idiots have not only a disturbed brain function but their entire organism is disarranged and growth processes upset." In the imbecile the same is true but to a less extent. While mild asymmetry in structure is proverbially normal, pronounced asymmetry is certainly more characteristic of the mentally defective as a class. In a careful study, La Page measured the skull conformation in a series of 198 cases of feeblemindedness and found lateral asymmetry in 158 , or 80 per cent., and, what is very interesting in this connection, 122, or 80 per cent. of these cases, showed the hypertrophy to be on the right side. This is in harmony with the ratio between right and left in our series of forty cases of total unilateral hypertrophy. Is it not probable that there is some fundamental similarity or even identity in the causes which produce pronounced cranial asymmetry and hemihypertrophy?

Little is known about the neuropathologic facts. In those cases which have come to necropsy the histologic study of the hypertrophied organs shows that the increase in bulk is due chiefly to an overgrowth of connective tissue. This fact again establishes a possible connection with feeblemindedness. Indeed there is a clinical form of mental defect which is known as hypertrophic amentia, which consists in an overgrowth of interstitial tissue. It may produce a skull, square in shape, 25 inches in circumference. Although this type of amentia is rare, sclerosis (or overgrowth of neuroglia) occurs frequently. Dr. Wilmarth 
examined the brains of 100 feeblninded children and found evidence of sclerosis in fully one fourth of the cases. Tredgold believes that in some of the cases it is probably due to vascular lesions.

Since hemihypertrophy consists in large measure of a diffuse sclerosis, it may be that we have the production of mental defect in those cases where the sclerosis involves one or both of the hemispheres. One cause would then be adequate to explain both conditions when they are associaterl.

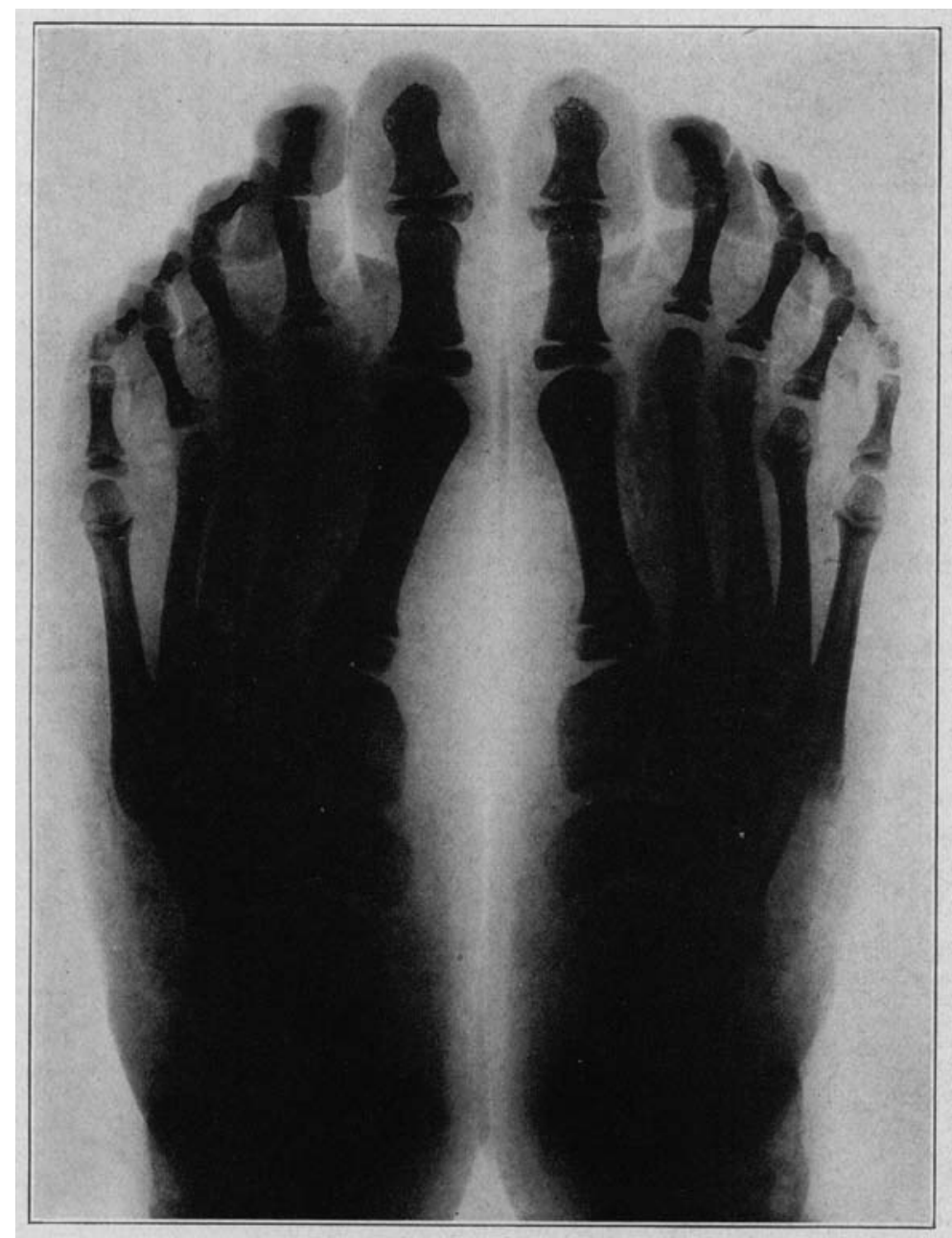

Fig. 7.-Roentgenogram of feet of subject at age of 13 .

Furthermore, if the exciting cause of these vascular lesions in the great majority of cases, as (rreig suggests, is an intra-uterine meningitis or cerebritis, we have an additional factor for the production of mental clefect. 
Dr. Gordinier's case of unilateral hypertrophy came to necropsy, but the brain, unfortunately, did not come to microscopic section. The viscera in general showed a diffuse interstitial connective tissue hyperplasia. The left cerebral hemisphere on inspection was distinctly larger than the right, and on measurement proved to be $1 \mathrm{~cm}$. greater in its anteroposterior and $1.25 \mathrm{~cm}$. greater in its transverse diameter. The intelligence of the subject was reported normal.

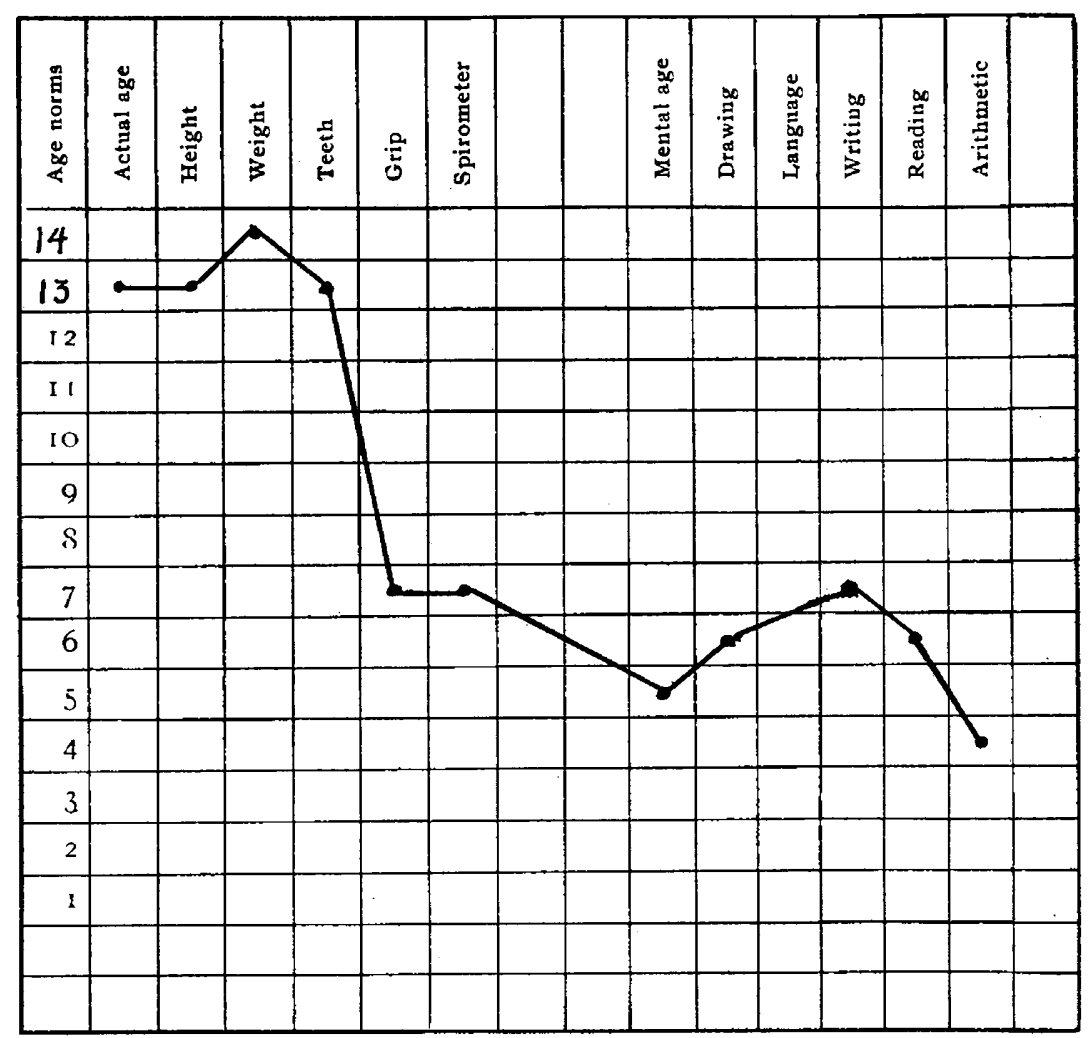

Fig. 8.-"Norm graph" showing standards of physical and mental development.

The production of actual mental defect in any particular case may therefore be contingent on the degree to which neurogliosis has taken place, and to the degree of compensatory development in unaffected nerve tissue.

It is possible that there are different causes for different cases of hemihypertrophy, and it may be that each case represents its own distinctive interaction between some intimate defect in the symmetry determiners and the environment of the multiplying cells. It is tempting, however, to relate true hemihypertrophy and certain not infrequent 
forms of cranial asymmetry to some quantitative abnormality in the chromosomal mechanism, which produces not only a deviation in the process of bilateral twinning, but also may upset normal tissue relations, increasing the proliferation of certain cells at the expense of others.

This is not out of harmony with Boveri's suggestion that an imperfect or irregular division of the chromosomal complex may, through loss of specific chromosomes, remove regulative inhibitions which permit certain inimical or normally suppressed cells to run wild.

The frequent association of hemihypertrophy and of cranial asymmetry with mental defect and the consistent preference in both conditions for enlargement of the right side suggests some lawful grouping of causative factors. It is quite possible that the origin of certain altogether obscure cases of secondary amentia may lie in an undetectable but decisive imbalance of the fundamental process of twinning which follows fertilization.

Whatever our final hypothesis may be, we seem to be warranted in the broad conclusion that true hemihypertrophy consists in an erroneous deviation from the normal course of development in the embryo, and carries with it, as so many anomalies of development do, the possible penalty of mental defect.

\section{SUM MARY}

Hemihypertrophy is a unilateral enlargement of one side of the body, and is one of the rarest among developmental anomalies.

A case associated with mental deficiency is described. Physical and mental measurements were made when the subject was 13 years old and repeated at the age of 20 .

A comprehensive tabu'ation of cases to date (Table 3) shows a total of forty cases recorded in medical literature, of which nineteen were male, twenty-seven on the right side, nineteen with skin complications and five with mental defect.

A less complete tabulation of partial and crossed hypertrophies, including thirty cases, is presented for comparison in Table 4.

In a discussion of the etiologic theories for hemihypertrophy, preference is given to the view that hemihypertrophy is not a hereditary character but a morphogenetic anomaly dating back to an early embryonic stage.

Hemihypertrophy is interpreted as a form of asymmetry due to a possible deviation in the normal process of twinning.

The complication of mental defect is attributed to an abnormality in the process of bilateral twinning which involves a disturbance of normal tissue development. 
Possible relations of certain cases of mental defect to cranial asymmetry and intra-uterine meningitis are suggested.

The value of further biometric and clinical studies in asymmetry is indicated.

\section{BIBLIOGRAPHY}

Adams, J.: A Singular Case of Hypertrophy of the Right Lower Extremity, Lancet 2:140, 1858.

Adams, S. S.: A Case of Hemihypertrophy, Arch. Pediat. 2:501, 1894.

Adler: Ueber partiellen Riesenwuchs, Berl. klin. Wchnschr. 32:110, 1895.

Ahlfeld, F.: Die Missbildungen des Menschen, Leipzig, F. W. Grunow, 18801882, vol. 1 .

Arnheim: Ueber einen Fall von congenitaler halbseitiger Hypertrophie mit angeborenen Bronckiektasien, Virchows Arch. f. path. Anat. 154:300, 1898.

Ballance, C. A.: Hemihypertrophy of the Head and Hypertrophy of Certain Toes, Trans. Med. Soc. Lond. 13:516, 1889-1890.

Ballantyne, J. W.: Manual of Antenatal Pathology and Hygiene, Edinburgh, W. Greene \& Sons, 1904, p. 257.

Bankhart, A. S. B.: A Case of Hypertrophy of the Right Side of the Face, Proc. Roy. Soc. Med., Lond. 9: Sect. Stud. Dis. Child., 77, 1915-1916.

Bassoe, P.: Unilateral Hypertrophy Involving the Entire Left Side of the Body, Worcester State Hosp. Papers 61:1912-1913.

Bateson, W.: Problems of Genetics, New Haven, Yale Univ. Press, 1913, p. 258 .

Beck: Abnorme Grösse des Daumens und des Zeigefingers der rechten Hand, Med. Ann. von Chelius u. Naegle, Heidelberg 2:89, 1836.

Bornaud: Observations histologiques sur un cas d'hypertrophie musculaires unilateral, Lausanne, 1891.

Broca: Journal of Physiology, Brown-Séquard 2:70, 1859.

Brüning, H.: Ueber angeborenen, halbseitigen Riesenwuchs. München. med. Wchnschr. 51:385, 1504.

Bull, G. J.: A Case of Bifurcated Foot with Eleven Toes, Boston M. \& S. J. 93:293, 1875 .

Burlet: Gaz. méd. dé Lyon, July, 1862, p. 309.

Cagiati, L.: Klinschr. und pathologischer Beitrag zum Studien der halbseitigen Hypertrophie, Deutsch. Ztschr. f. Nervenheilk. 32:282, 1907.

Chassaignac: Hypertrophie congénitale des deux membres droits, Bull. Soc. de chir, de Paris 8:452, 1857-1858.

Cohen, Hyman: A Case of Hemihypertrophy with Increased Sugar Tolerance, J. A. M. A. 69:463 (Aug. 11) 1917.

Curling, T. B.: Case of Remarkable Hypertrophy of the Fingers in a Girl, Med. Chir. Trans. Lond. 28:452, 1845.

Davidson, A. J.: A Case of True Congenital Unilateral Hypertrophy, Med, Rec. 80:420, 1911.

Demme: Ueber einen eigenthümlichen Fall von angeborener halbseitiger muskel Hypertrophie, Wien. med. B1. 13:17, 1851.

Desvouges: Bull. Soc. anat. de Paris 31:510, 1855.

Eaton: Brit. M. J. 1: 1886. 
Fatichi: Sperimentale, Fir., 1895.

Finlayson, J.: On the Case of a Child Affected with Congenital Unilateral Hypertrophy and Patches of Cutaneous Congestion, Glasgow M. J. Ser. 4 22:327, 1884.

Fortescue-Brickdale, J. M.: A Case of Congenital Hemihypertrophy, Lancet 189: 10, 1915.

Foucher: Excessive Development of the Left Arm and Leg, Bull. Soc. anat. de Paris 25:108, 1850.

Friedberg, H.: Riesenwuchs des rechten Beines, Virchows Arch. f. path. Anat. 40:353, 1867.

Friedreich, N.: Ueber congenitale halseitige Kopfhypertrophie, Virchows Arch. f. path. Anat. 28:474, 1863.

Gesell, A.: Present article. See also Psychol. Bull. (Summary) January, 1919.

Goddard, H. H.: The Causes and Consequences of Feeblemindedness, New York, Macmillan Co., 1914.

Goddard, H. H.: The Height and Weight of Feebleminded Children, J. Nerv. \& Ment. Dis. 39:217, 1912.

Gordinier, H. C.: A Case of Unilateral Hypertrophy of the Whole Left Side with Necropsy, Albany M. Ann. 39:47, 1918.

Gould: Anomalies and Curiosities of Medicine.

Greig, D. D.: Unilateral Hypertrophy, Edinburgh Hosp. Repts. 5:212, 1898.

Gruber, W.: Ueber einen Fall von Macrodactylie bei einen Lebenden, Virchows Arch. f. path. Anat. 56:416, 1872.

Harrison, R. G.: On Relations of Symmetry in Transplanted Limbs, J. Exper. Zool., Balt. 32:1, 1921.

Hoffmann, M.: Zur Pathologie des angeborenen, partiellen Riesenwuchses, Beitr. z. klin. Chir. Tübingen 48:391, 1906.

Hornstein, S.: Ein Fall von halbseitigen Riesenwuchs, Virchows Arch. f. path. Anat. 133:440, 1893.

Hutchinson, J.: Hypertrophy of the Left Side of the Body in an Infant, Rept. Soc. Stud. Dis. Child., Lond. 3:194, 1902.

Hutchinson, R.: Report of a Case of Hemi-Hypertrophy with Post Mortem Examination, Proc. Roy. Soc. Med., Lond. 9: Sect. Stud. Dis. Child. 66, 19151916.

Jacobi, A.: Am. J. Obst. 4:321, 1871.

Lapage, C. P.: Feeblemindedness in Children of School Age, Manchester, Univ. Press, 1911.

Langlet: Hypertrophie congénitale de la moitié droite du corps, Union méd. et scient. du nord-est, Reims $6: 276,1882$.

Leblanc, E.: Thése pour le doctorat en médecine. Contribution a l'etude de l'hypertrophie congénitale, unilaterale partielle ou complete, Paris, Henri Jouve, 1897.

Lewin, G.: Studien über die bei halbseitigen Atrophien und Hypertrophien, namentlich des Gesichtes, Charité-Ann., Berl. 9:619, 1884.

Logan: Hypertrophy of the Right Half of the Body in a Child Aged Four Years, New Orleans J. M. 21:733, 1868.

McConnell, J. W.: A Case of Hemihypertrophy, Arch. Neurol. \& Psychiat. 2:136 (July) 1919.

McConnell, J. W.: Hemihypertrophy, J. Nerv. \& Ment. Dis. 50:348, 1919. 
McGregor, A. N.: A Remarkable Case of Unilateral Hypertrophy in a Child, Glasgow M. J. 41:189, 1894.

Maschke, A. S.: Unilateral Hypertrophy of the Leg with Congenital Misplacement of Striped Muscle Tissue of the Foot, Cleveland M. J. 6:194, 1907.

Milne, B.: Report of a Case of Congenital Asymmetry, Lancet 1:752, 1895.

Milne, J. B.: On the Case of a Child Affected with Congenital Symmetry of the Two Halves of the Body, Quart. M. J., Sheffield 3:245, 1894-1895.

Möbius: Ueber Hemihypertrophy, München. med. Wchnschr. 37:751, 1890.

Monod, A., and Trélat, U.: De l'hypertrophie unilatérale partielle ou totale du corps, Arch. gén. de méd. 1:536; 676, 1869

Morgan, T. H., and Bridges, C. B.: Contributions to the Genetics of Drosophilia Melangaster (The Origin of Gynandromorphs) Washington, Carnegie Institute, 1919.

Mummery, P. L.: A Case of Hemihypertrophy, Proc. Roy. Soc. Med., Lond. 1: Clin. Sect. 61, 1907-1908.

Newman, H. H.: The Biology of Twins, Chicago, Univ. of Chicago Press, 1917.

Newman, H. H.: Heredity and Organic Symmetry in Armadillo Quadruplets. II. Mode or Inheritance of Double Scutes and a Discussion of Organic Symmetry, Biol. Bull. 30:173, 1916.

Ollier: Gaz. méd. de Lyon, 1862.

Osler, W.: Case of Congenital and Progressive Hypertrophy of the Right Upper Extremity, J. Anat. \& Physiol., Lond. 14:10, 1879-1880.

Parhon, C. J., and Severin: Sur un cas d'hémi-hypertrophie cranio-faciolinguale, avec trophoedème facial, N. iconog. de la Saltpêtrière 28:282, 1916-1917.

Passauer, O.: Angeborne Hyperplasie der linken Gesichtshälfte, Virchows Arch. f. path. Anat. 37:410, 1866.

Pershing, H. T.: Unilateral Hypertrophy of Limbs; Report of a Case, J. Nerv. \& Ment. Dis. 40:46 also 65, 1915.

Pollosson: Lyon méd., 1884.

Redard, P.: De l'hypertrophie congénitale partielle, Arch. gén. de méd. 1:31, 1890 .

Reismann: Un cas de gigantisme unilateral avec hypertrophie de l'hemisphere cerebrale du cete opposé, Ann. de méd. et chir. 6:793, 1902.

Reismann: Further Note on a Case of Unilateral Gigantism, Australasian M. Gaz, $23: 280,1904$.

Schiller, M.: Totale Hypertrophie einer Körperhälfte, Berl. klin. Wchnschr. 47:366, 1910 .

Silverstrini, L.: Su di un caso d'ipertrofia congenita parziale, Clin. chir. Milano, 22:581, 1914.

Speese, J.: Unilateral congenital hypertrophy, Arch. Pediat. 31:278, 1914.

Steffen, W: : Angeborene Hypertrophie der einen Körpeherhälfte, Jahrb. f. Kinderh. 38:379, 1894.

Telford, E. D.: Hemi-Hypertrophy of the Body with Naevus and Varicose veins, Lancet 2:129, 1912.

Thomson, J.: On a Case of Myxoedematoid Swelling of One Half of the Body in a Sporadic Cretin, Edinburgh M. J. 37:249, 1891. 
Tilanus, C. B. : Ueber einen Fall von hemihypertrophia dextra, München. med. Wchnschr. 40:65, 1893.

Tuckerman, F.: Some Observations in Reference to Bilateral Asymmetry of Form and Function, J. Anat. \& Physiol. 19:307, 1885.

Turbil: Gior. d. r. Accad. di med. di Torino, 1896.

Velebil, A.: Hemihypertrofia congenitalis, Rev, v neuropsychopath., Praha 10:577, 1913 .

Wagner, P.: Zur Casuistik des angeborenen und erwobenen Riesenwuchses, Ztschr. f. Chir., Leipzig, 26:281, 1887.

Widenmann, A.: Ueber partiellen Riesenwuchs. Bietr. z. klin. Chir., Tübingen, $8: 625,1892$.

Wieland, E.: Zur Pathologie der dystrophischen Form des angeborenen partiellen Riesenwuchses, Jahrb. f. Kinderh., Liepz. 65:519, 1907.

Wittelshöfer, R.: Ueber angeborenen Riesenwuchs der oberen und unteren Extremitäten, Arch. f. klin. Chir. 24:57, 1879. 